University of Warwick institutional repository: http://go.warwick.ac.uk/wrap This paper is made available online in accordance with publisher policies. Please scroll down to view the document itself. Please refer to the repository record for this item and our policy information available from the repository home page for further information.

To see the final version of this paper please visit the publisher's website. Access to the published version may require a subscription.

Author(s): JAMES BRASSETT AND RICHARD HIGGOTT Article Title: Building the normative dimension(s) of a global polity

Year of publication: 2003

Link to published version: http://dx.doi.org/

10.1017/S0260210503005898

Publisher statement: None 


\title{
Building the normative dimension(s) of a global polity
}

\author{
JAMES BRASSETT AND RICHARD HIGGOTT
}

\section{Introduction}

Globalisation is not what it used to be. Earlier debates over how to read the indicators of economic liberalisation and the impact of technological expansion have now been joined by the increasingly pressing need to explore the social, environmental and political aspects of global change. Earlier discussions emphasised a number of dichotomies within the international political economy - open/closed, state/market and so on. These have proved limited in their ability to inform explanations of change under conditions of globalisation. To these we must now add what we might call the 'governance from above', 'resistance from below' dichotomy as a popular metaphor for understanding order and change in international relations under conditions of globalisation. But this new binary axis is in many ways as unsatisfactory as those that went before. It too can obscure as much as it reveals in terms of understanding the normative possibilities of reforming globalisation. In this article we wish to suggest that there is perhaps a more useful way of thinking about politics and the changing contours of political life in the contemporary global order. This approach blurs the distinction between governance and resistance by emphasising an ethical take on globalisation.

Building on some innovations in social theory that have found their way into international relations scholarship we stress the need for a permanently reflexive relationship between meta-theory, social, political and economic theory and policy practice at the global level. The social science academy, especially the tradition of neoclassical economics, offers (both explicitly and implicitly) much more than mere scholastic meditation. As we have long known, it informs the practical horizons for the policy community. Academic understanding is not simply the depoliticised provision of technical mechanisms for governing (or not governing). It is itself a political act that casts massive shadows over policy.

Globalisation is not simply 'out there'. It is constructed through our understandings of communicative practices. A self-conscious promotion of theoretical innovation as a political act is not an exercise in reflection for its own sake. Any attempt to understand and explain the nature of social structures and processes must subsequently provide a normative justification for a chosen preferred approach. As a critique of rationalism, the identification of the epistemology of power (the major strength of postmodernism) is not, of itself, sufficient. It must be accompanied by a self-conscious normative intent if we are to build the ethical dimensions 
of globalisation. If, to borrow a phrase, globalisation is what we make of it, the content of 'what' and the group that is 'we' are ethical questions of direct policy relevance to the contemporary global political economy. This article seeks to draw together a redescription of globalisation as both an ethical and political question with the bones of a reformist way of considering how to socially re-embed its more technocratic and economistic elements.

Apart from the work of a few notable, though often politically marginal authors, this normative facet of globalisation has either been ignored, or worse still, assumed to be a commonly agreed objective. This was invariably the case amongst leading globalisers - that is, proponents of the continued liberalisation of the global economic order occupying positions of influence in either the public or the private policy domains - during the 1990s. But it was also often the case in the community of academic economists interested in globalisation, for whom there has been an unproblematic conflation of economic growth with human welfare on the one hand, and the subsequent marginalisation of any reflective normative theorising about issues of justice in the policy domain on the other. For a range of reasons, including the efforts of resistance-based political groups, the period since the late 1990s has seen a recognition of this lacuna in both the global policy community and the scholarly economic community. ${ }^{1}$

This under-representation of the normative dimension of globalisation throughout the 1990s was, with a few exceptions, as much a weakness of (international) political theory as it was a failure of neoliberal economic theory and policy practice to engage the ethical underpinnings of economic globalisation. ${ }^{2}$ As currently constituted, the institutions of global economic governance, and the rationalist theories of liberal economy which underpin them, offer little in the way of substantive, ethically sophisticated, political agendas for humanising globalisation. ${ }^{3}$ Similarly, as currently constituted, competing cosmopolitan theories of international relations or liberal political philosophies of justice, upscaled to the global level, exhibit too little an appreciation of the dynamic(s) of the market place to offer meaningful ways of addressing the political legitimacy deficit in the global economic order. It is only in the creation of a dialogue across the domains of economics, political theory and policy practice that meaningful mechanisms for reform are likely to emerge. The article therefore seeks to operationalise a conception of justice via a redescription of globalisation as an explicitly political and ethical issue.

Our first section adopts an analytical focus that takes account of the extant sociopolitical transformations associated with globalisation. It aspires to a better understanding of the preponderance of non-state actors and competing sites of

1 For an analysis of the mood swing that is causing a major rethink about the normative dimensions of the globalisation project, see Richard Higgott, 'Contested Globalisation: the Changing Context and Normative Challenges', Review of International Studies, 26 (2000), pp. 131-53.

2 But see the essays in Andrew Hurrell and Ngaire Woods (eds.), Inequality, Globalisation and World Politics (Oxford: Oxford University Press, 1999), and Thomas Pogge (ed.), Global Justice (Oxford: Blackwells, 2001). See also Chris Brown, Sovereignty, Rights and Justice (Cambridge: Polity Press, 2002).

3 For an explanation of these limitations, see Richard Higgott, 'Taming Economics, Emboldening International Relations: The Theory and Practice of International Political Economy in an Era of Globalisation', Stephanie Lawson (ed.), The New Agenda for International Relations: From

Polarisation to Globalisation in World Politics (Cambridge: Polity, 2002). 
authority in the global system than can be captured by 'systemic' or 'international society' theorising. To that end the article makes a cursory delineation of the contours of what has been called elsewhere 'a global polity' and outlines some of its central points of contest. By this we do not mean that there is a world government, or that politics is no longer inter- or intra-state focused. Rather it is observed that the extant global space provides for a different, and emerging form of politics that requires alternative theoretical elaboration. ${ }^{4}$

A return to ethical theory might allow us a different and (potentially) more constructive way of regarding the development of the global polity than is gleaned from economically rationalist accounts of globalisation on the one hand, or some of the more traditional veins of international theory on the other. In both its problematisation of the relationship between individuals/groups and institutions, and in its preoccupation with the question of community, ethical theory in international relations - be it cosmopolitan or communitarian - represents a conduit into the politics of the global polity. But, we argue, this utility as a conduit does not necessarily lead to a meaningful agenda for change.

Our second section therefore examines the difficulties of extracting a 'practical' ethic commensurate with a broad-based political reform of globalisation. The debate between cosmopolitanism and communitarianism itself highlights the problem of achieving a standard of justice in a world of different sociocultural particularities and realistic power structures that delimit the "arc of possibilities' ${ }^{5}$ open to practitioners. It is all very well to suggest ethical utopias, but quite another thing to find agreement on their content, or 'convince' the deep structures of political, social, economic, and psychological interests at work in the global polity of their desirability.

In its more predictive forms the communitarian position - as it is understood within IR - is found to equate ethics with power, since most of the 'stuff' of ethical politics is reduced to the relations between, rather than within, communities. This article proposes that the strength of the communitarian position has perpetuated a tradition of middle-way theorising in IR. Pace the English School and Neoliberal Institutionalism, much speculation on the normative dimension(s) of the global polity has been presaged upon the need to reconcile the competing claims of individuals (usually read as a universal given) and communities (usually read as states). Whilst laudable, such philosophical refinement, even in those most sophisticated of renderings provided by, say, Andrew Linklater, ${ }^{6}$ may be more exemplary of the limitations of normative theorising for the global polity than the possibilities that could be built. Indeed, the very framing of this debate may itself act to constrict the possibilities for engagement. Foundationalist arguments may simply waste too much intellectual energy attempting to define 'what is' in order to legitimise their arguments for 'what should be'?

4 For an elaboration of this line of argument, see Richard Higgott and Morten Ougaard, 'Beyond System and Society: Towards a Global Polity?' in Morten Ougaard and Richard Higgott (eds.), $A$ Global Polity (London: Routledge, 2002).

5 Jim George, 'Creating Globalisation: "Patriotic Internationalism" and Symbiotic Power Relations in the Post WW2 Era', Working Paper 66/01, University of Warwick: Centre for the Study of Globalisation and Regionalisation, January 2001.

6 See his Transformation of Political Community: The Ethical Foundations of the Post Westphalian Era (Cambridge: Polity, 1998). 
Thus, in the third section we suggest that the anti-foundationalist pragmatism of Richard Rorty offers a more interesting and practical philosophical question of 'what could be?' In this we follow previous work in normative IR that notes the heuristic utility of the cosmopolitan-communitarian debate while suggesting its ultimately constraining nature. By applying Rorty's thought to the salient political issue of globalisation, this article seeks to contribute towards the work of those contemporary international theorists who have engaged Rortian pragmatism. ${ }^{7}$ We draw on Rorty's work to make an argument in favour of a pragmatic praxis as a viable means of developing understanding(s) of, and the normative potential within, the global polity.

In the simple and under-theorised sentimentality of the Rortian ethic of redescription we find an imaginative springboard for launching a reformist agenda. Rortian pragmatism is advanced for its 'enabling qualities'. Firstly, it enables us to view our approach as both contingent and fallible, thus imploring us to build the normative agendas we support. Political praxis is central to such theory/practice. And secondly, it enables us to view our approaches as experimental. Rather than losing ourselves in some ethic that 'changes the world' we should instead focus our energies upon 'small' experimental approaches to issues like poverty, selfishness, technocratic ignorance, depoliticised economism, the achievement of 'voice' for those accustomed to going without it, and institutional reform. These agendas alone will not solve all problems, rather they offer a focus and a drive to realise the (more) normative dimension(s) that the global polity could potentially harbour.

By combining a political ontology of globalisation with an ethic of pragmatic reformism we raise the salience of the role of sympathy and hope in the everyday practices of the global polity. The propensity to elicit and actualise ethical values is a function of the reflexive interrelations of multiple actors (international organisations, states, NGOs, civil society, MNCs, financial market actors) operating at multiple levels (international, supra-territorial, regional, local, and through the media) within the global polity. There is no ethical end game to be realised: just a more ethically and politically aware set of games to be played. In section four we offer some initial and rudimentary suggestions about what pragmatic redescription in the global polity might mean.

\section{Towards a global polity?}

Globalisation is an often-used and radically underspecified term. It has been variously ascribed the characteristics of economic liberalisation, internationalisation, universalisation, Westernisation, and deterritorialisation. ${ }^{8}$ Causal dynamics

\footnotetext{
7 Chris Brown, International Relations Theory: New Normative Approaches (New York: Columbia University Press, 1992) and on Rorty: 'Universal Human Rights: A Critique', in Tim Dunne and Nicholas Wheeler (eds.), Human Rights in Global Perspective (Cambridge University Press, 1999), and Molly Cochran, Normative Theory and International Relations (Cambridge: Cambridge University Press, 1999).

8 For the best introductory discussion, see Jan Aart Scholte, Globalisation: A Critical Introduction (London: Macmillan, 2000).
} 
differ between perspectives but they all include some notion of heightened economic, communicative, and technological interconnection. Although elements of globalisation can be analytically separated and falsified, or not falsified, in this way, in this article we use a minimalist conception of globalisation as the creation of an extensively (though not uniformly) interconnected and contested global space. It is in the nature and extent of this interconnection and contest that globalisation provokes a number of questions that - by their very nature - serve to politicise the global space.

In the most popularly received and most criticised reading, globalisation heralds the dawn of a universal space in which the divisive influences of nationalism, ethnicity, and religion will be transcended by secular modern liberal democracy. ${ }^{9}$ In its more economistic interpretations the thesis has been bound up with the growth of a global market for goods and services which, left unfettered, will break free from the shackles of state regulation. In the 1990s globalisation for many governments appeared to become a 'normalising discourse' of power that conditioned policy responses to the perception, if not always the reality, of global market integration.

As we now appreciate, this hyper-globalist view over-egged the ascendancy of the market and was too quick to write off the importance of the state both politically, and as Paul Krugman has recently noted, economically. ${ }^{10}$ Such rhetorical depictions of the state as 'withering' or 'retreating'11 prompted a sustained backlash from within a number of scholarly circles that sought to re-establish the importance of the state as the main actor in international relations. ${ }^{12}$ Indeed much of the initially popular and populist debate over globalisation turned on a rationalist-driven 'states vs. markets' dichotomy. Such a seemingly zero-sum contest belied a capacity of the state to secure a more gradual transformation in state-market relations; or, a positive-sum diffusion of power amongst non-state actors operating in multiple sites of authority in the global system.

A subtler rendition of the relationship between states and markets sees it as a perpetual process of reconstruction of the mechanisms for sustaining capitalist accumulation in an era of global structural change. From this standpoint, we can accept the augmented power of the structures of global finance and production, whilst recognising that there is still no substitute for the state as the repository of sovereignty and rule-making and as provider of national security. But it is a state that is in a process of adaptation. States have been joined by a host of non-state actors operating at multiple sites of authority - both public and private - in the global policy process. ${ }^{13}$

9 Quintessentially, see Francis Fukuyama, The End of History and the Last Man (Harmondsworth: Penguin, 1992).

10 Paul Krugman, The Return of Depression Economics (London: The Allen Lane Press, 1999).

11 See Kenichi Ohmae, The End of the Nation State (London: Harper Collins, 1995) and Susan Strange, The Retreat of the State: The Diffusion of Power in the World Economy (Cambridge: Cambridge University Press, 1996).

12 For restatement of the strength of the state, see Paul Hirst and Grahame Thompson, 'Globalization a Necessary Myth?' in David Held and Anthony McGrew, The Global Transformations Reader: An Introduction to the Globalization Debate (Cambridge Polity Press, 2000).

13 See the essays in Claire Cutler, Virginia Haufler and Tony Porter (eds.), Private Authority and International Affairs (New York: SUNY Press, 1999) and Richard Higgott and Geoffrey Underhill and Andreas Bieler (eds.), Non-State Actors and Authority in the Global System (London: Routledge, 2000). 
A diffusion of power and influence through international organisations like the IMF, World Bank, WTO, EU, and BIS, as well as the growing salience of private and voluntary regulatory bodies has meant a complex expansion, no matter that it is contested terrain, of the public sphere. There has, in short, been a 'globalisation of political life'. Three elements underwrite the claim for the emergence of the nascent 'global polity':14

1. Most obviously, there is a growing political interconnectedness. This is a phenomenon recognised several decades ago, ${ }^{15}$ but interconnectedness in a global polity, as opposed to traditional understandings of the international system or society, is not only between states, but also supra-, sub- and non-state actors.

2. There is a vast and interlocking network of global regulation and sites of decision-making where policies of a (quasi-) global nature are made. We include in this category the (international) institutions of global governance: the IMF, World Bank, WTO, the UN agencies as well as the growing (if underexposed) salience of organisations of private and non-state regulation in areas such as credit rating and industry standards setting. That ratings agencies like Moodys and Standard and Poors can strongly influence the economic fortunes of states is surely a political relation as much as an economic one. ${ }^{16}$

3. A more difficult dimension of this process to capture, but no less important for that, is the growing sense of 'community' that appears to be developing beyond the confines of the state. As Robertson would have it, globality is defined in the context of a consciousness '. . . of the world as a single place'. ${ }^{17}$ This is not to suggest the emergence of a common set of global values, rather to indicate the growth of thinking about 'the world' as an identifiable sense of place or space where different values can legitimately contest one another. A quintessential fact of international political life has been the multiplication of global gatherings that argue over the validity of a multiple array of global principles and practices. $^{18}$

It could even be argued that the contestable efficacy or legitimacy of these institutions is itself a salient feature in the politics of the global polity. Even if states and non-state actors are in disagreement about the norms and principles that are emerging, in practice, by the very fact that they contest the nature of these principles and practices in global assemblies and other instances of global public space, it has the consequence (unintended as it may be) of furthering the development of a global

14 The discussion in this section draws on Higgott and Ougaard, Global Polity.

15 See Robert O Keohane and Joseph Nye, Power and Interdependence (Boston, MA: Little Brown, 1977).

16 See T. J. Sinclair, 'Passing Judgement: Credit Rating Processes as Regulatory Mechanism of Governance in the Emerging World Order', Review of International Political Economy, 1: (1994), pp. 133-49.

17 Roland Robertson, Globalisation, Social Theory and Global Culture (London: Sage, 1992), p. 132.

18 These can range from meetings of small non-governmental organisations (NGOs) and Global Social Movements (GSMs), through to the UN conference system. Gatherings at the global level cover issues as diverse as gender, development, environment, welfare, cities, security to the Davos gatherings of the rich and powerful of the private (and public) sector policymaking world and their counterpart gatherings such as the Porto Allegro World Social Forum. 
polity. On this view we might be able to understand realist or mercantilist positions regarding globalisation for what they are - that is, coherent attempts to contest the political meaning, and therefore social outcomes, of decision-making within the global polity.

Governance, resistance and the possibilities for reform

To refine the analytical focus, we wish to talk about something more than traditional state-centred understandings of world politics, as 'systemic' or 'societal' on the one hand (still the principal mode of reasoning in international relations scholarship along a Waltzian structuralist-international society/English School spectrum) but as something less than a single complex of enforceable societal relationships on the other. Greater attention has to be paid to the changes in the quality and quantity of global structural change. Financial interconnections over recent decades have had a profound effect upon the capacity of states to pursue national welfare options. This is not simply to privilege structure at the expense of agency. States remain important actors in world politics. But they have been joined by a host of non-state actors that actively 'transcend' territorial politics in an attempt to realise their interests at multiple levels, including the institutions of supra-territorial governance. To this extent they are the players in the polity. Agents that would have once focused most of their attention on attempting to influence the policy process within national polities now channel more energy than in the past towards securing influence beyond the boundaries of the state.

Most notably, there have been a number of significant points of resistance to globalisation that have contested the free-market fundamentalism of the 1990s Washington Consensus (WC) and ushered in a period of more socially aware governance. For brevity's sake we term this the era of the Post-Washington Consensus (PWC). ${ }^{19}$ Some key events and features of this era include the failure of MAI, the financial crises in Latin America, East Asia and Eastern Europe, the semiinstitutionalisation of the anti-globalisation movement from Seattle on and, perhaps most importantly, the growing belief that globalisation is at least correlated with, if not proven to be causally related to, vast income differentials at the global level. These have been focal points for the critical activities of an ever-burgeoning global civil society. By contesting globalisation and the market orthodoxies of the earlier 'Washington Consensus' era through active public engagement, these events have brought to the public sphere a metapolitics of instititutional legitimacy in which the procedures of the global governance are subjected to greater public scrutiny than at any time since their inception in the Bretton Woods era. Whether this process is itself legitimate - according to the efficiency models of governance popular amongst the policy communities that inhabit the corridors of the IMF, World Bank, and WTO or not, is itself contested.

19 We are aware of the contentious and clichéd status of the terms 'Washington and post-Washington consensus'. We use them to capture the changing international mood at the end of the twentieth century. 
The important point for this article is that this growing public engagement, through non-state actor pressure, has had an impact. Governance is not merely resisted: interaction has on a number of occasions led to reform. A mood swing in the global governance agenda has led to an increased concentration on a more socially aware rhetoric of economic globalisation. In turn this has gone some way towards a recognition that globalisation has to be politically socialised, legitimised and democratised if the wider gains of the economic liberalisation process are not also to be lost to its major beneficiaries. But we are at the beginning, not the end, of this process of political deliberation. With neither agreement on the scope of the global polity, nor the institutions of global governance strong enough to administer to it, the global polity remains nascent and contested.

By reflecting such dynamics, we aim to demonstrate the inherent interrelationship, and normative value, of political contest, governance and reform. Importantly for this article, the growing salience of new actors in the formulation of public policy renders governance as a process more akin to 'political negotiation' weak and inhibited as it may be - rather than merely 'efficient administration'. It is this latter view - governance as efficient administration - that roughly approximates the position of many in the policy community influential over the shape and course of globalisation. After the exposure of the institutions of the Washington consensus to the failures of the late 1990s and the resultant contest over the substantive content of future policy, 'governance' was a term that gained prevalence in the scholar cum policy community. In the recent public policy literature, governance refers to '.... the development of governing styles in which boundaries between and within public and private sectors have become blurred'. ${ }^{20}$ But this definition neither notes the way globalisation has also blurred the domesticinternational divide as material fact, nor the longer term historical development of systems of emerging international norms and regimes (both public and private) that represent the elements of a framework of 'governance without government' under globalisation. ${ }^{21}$

In this way, the hosting metaphor of the global polity allows us to situate the politics of 'contested globalisation' within the context of broader debates over governance within International Relations. ${ }^{22}$ Understanding of, and attention to, the importance of normative questions of governance and state practice as exercises in accountability and democratic enhancement must catch up with our understanding of governance as exercises in effectiveness and efficiency. In this way 'politics', as opposed to 'efficiency', comes to occupy a more significant place in the discourse of globalisation than much of the contemporary literature reflects. More importantly for this article, with the introduction of politics as an explicitly normative concern, the global polity is rendered susceptible to ethical scrutiny and questions of legitimacy and justice, in a manner not possible under the hegemony of a neoliberal economic orthodoxy of the Washington consensus era.

20 Gerry Stoker, 'Governance as Theory: Five Propositions', International Social Science Journal, 155 (1999), p. 17.

21 See the pioneering essays in Ernst Otto Czempiel and James N. Rosenau, Governance without Government: Order and Change in World Politics (Cambridge: Cambridge University Press, 1992).

22 See Higgott, 'Contested Globalisation', pp. 131-53. 


\section{The ethical dimension(s) of the global polity}

In the reading we advance here, and we recognise that it might not be the only reading, the debate between cosmopolitans and communitarians can usefully help theorise the global polity for two reasons. Firstly, the status of individuals vis à vis states and other institutions is understood as a core point of ethical debate. Whether we accept the cosmopolitan view that man qua man is the ontological site for ethical deliberation on the one hand, or the communitarian riposte on the other that an acultural, ahistorical notion of individuality is simply untenable, it is clear that the rise of supraterritorial relations within the global polity goes to the heart of some profound philosophical questions. That the two debates should be combined appears self-evident.

Secondly, in the tensions between universalism and particularism, which the debate exposes, we can find illustrations of the kind of questions that can and should be posed of international organisations, states, capital markets, civil society, and MNCs. In the transnational spread of capitalist arrangements we discern a number of contests over market structure, regulation standards, credit agreements, and social welfare that are increasingly resolved within institutions of global governance. Whether we regard this as an opportunity (as yet unrealised) to institute universal standards for the global polity, or as an example of the putative particularist domination of the world through the ascendancy of the Anglo-Saxon model of capitalism, this contest will determine the way we frame the ethical dimension(s) of the global polity. This section offers a generalised account of cosmopolitanism and contrasts it with a communitarian perspective, before engaging the 'thinner' cosmopolitanism of Andrew Linklater.

\section{Cosmopolitanism}

Cosmopolitanism takes the view that social institutions should be justifiable on the basis that they meet the 'basic rights' of individuals in respect of universal standards of justice, liberty and equality. Although this position is not presaged upon the interdependence of the world economy and resultant liberal optimism that accompanied the naïve language of early 1990s globalisation, ${ }^{23}$ it nevertheless attempts to construct notions of justice that draw upon and go some way towards constructing such an ideal. To the extent that human equality is a basic cosmopolitan world-view, the globalisation of technological and communicative linkages can be seen as a facilitator of cosmopolitan ethics. Although it is a large step from 'one world economy' to a 'community of mankind', cosmopolitans could highlight the ethical potentials of globalisation. Certainly when taken in the context of the end of the

23 At its most naïve, this language contended that 'two meta trends - fundamental technological change and a new ethos of openness - will transform our world into the beginnings of a global civilisation, a new civilisation of civilisations, that will blossom through the coming century', Peter Schwarz and Peter Leyden, 'The Long Boom: A History of the Future', Wired, July 1997, p. 116. 
Cold War and the genuine spread of 'freedoms' from ideological domination and militarism, there is some credence to this view.

More substantively, there is a raft of political changes concomitant with globalisation that could bring confidence to cosmopolitan positions. The division of the world into states is one manifestation of how reason can, in effect, 'globalise'. Norms of representation and the chance of peaceful stability amongst states represent an institutional medium for achieving universal standards. Add to that the growing auspices of international governance institutions and the global polity could be described as displaying what some have called 'embedded cosmopolitanism'. ${ }^{24}$ The burgeoning membership of bodies like the IMF, the WBG and the WTO certainly creates the administrative capacity for a universal constituency. Indeed, if such overtly market-oriented institutions could coordinate their policies with the appropriate departments of the UN, as envisaged in the turn of the century UNDP initiatives on governance and global public goods, and the UN's Global Compact with the private sector to promote human rights and raise labour and environmental standards, ${ }^{25}$ then an ethical cosmopolitan order could be considered a nascent reality.

However, as critics of cosmopolitanism would argue, the use of the word 'if' is crucial to this discussion. Indeed, the burden of political efficacy has been a central concern for late twentieth-century cosmopolitan theorists. One response has been to attach philosophical justification to extant changes associated with economic globalisation. In Political Theory and International Relations (1979), for example, Charles Beitz argued that interdependence in the global polity undermines the assumption common amongst political theorists - and John Rawls in particular that states are self-sufficient entities which represent the sole site of political and ethical discourse. ${ }^{26}$ From the perspective of the global polity outlined in our first section, this is an observation we would accept intuitively, at least. Certainly it opens the possibility for meaningful dialogue between political theory and IR. However, Beitz's development of this point serves rather to illustrate the institutional and political problems that cosmopolitanism must face when applied at the global level. He suggests that such extant trends in the international political economy could point to a 'global scheme of social co-operation. ${ }^{27}$ On this view, a case can be made for viewing individuals as the prime foundation of justice and elicit the possibility of global redistributive justice. This is strong stuff. By locating moral value in the individual, Beitz questions the empirical and ethical autonomy of states and therefore challenges the fundamental assumptions of both political theory and IR. Yet we feel that the argument is undermined on two counts, one institutional, one empirical.

24 See Toni Erskine, " Citizen of Nowhere" or "Point Where Circles Intersect"? Impartialist and embedded cosmopolitans', Review of International Studies, 28 (2002), pp. 457-78.

25 See Inge Kaul Isabell Grunberg and Marc A. Stern (eds.), Global Public Goods: International Cooperation in the 21st Century (New York: Oxford University Press for the UNDP and John G. Ruggie).

26 Charles Beitz, Political Theory and International Relations (Princeton, NJ: University Press, 1979). Much of Beitz's discussion is set up as a critique of the bounded nature of justice in John Rawls' $A$ Theory of Justice (Oxford: Oxford University Press, 1971). For the purposes of this article we concentrate on the side of Beitz's argument which focuses on economic interdependence.

27 Ibid., p. 149 
Firstly, although Beitz undermines the empirical and ethical strength of states by founding justice in the person of the individual, he concedes that states - as the central players in the global polity - will remain the primary mechanism for implementing any kind of redistributive justice at the global level. As Molly Cochran judges, on this view: 'international distributive justice applies only derivatively to states and principally to persons in the founding principles for the establishment of just social arrangements'. ${ }^{28}$ This appears to be a compromise argument that surely creates more problems than it solves. How one justifies the foundation of policy in the ethical value of individuals and then persuades (different) states to administer it, is a question that illustrates, rather than solves, the complexity of institutional arrangements in the global polity.

Secondly, by attaching universalist arguments for distributive justice to empirical rather than abstract criteria Beitz opens himself to empirical refutation. While interdependence has grown in the absolute, in certain parts of the world it remains very slight, even non-existent. If justice pertains to those areas with a higher level of interdependence because that represents a scheme for cooperative venture what becomes of those isolated areas less integrated into the global polity? Followed through to its logical conclusion, Beitz's argument would find a stronger case for redistributive justice in Europe than it would in sub-Saharan Africa. ${ }^{29}$ This counterintuitive point presses the need for a more nuanced appreciation of globalisation than simply a phenomenon of increased interdependence.

Further interpretations of the cosmopolitan tradition have taken this tack. David Held and Anthony McGrew have investigated the potential of the institutions of global governance for representation and accountability. ${ }^{30}$ This brand of cosmopolitan democracy seeks to highlight the deficits between the major sites of power and the dispossessed in the global polity. They propose a democratisation along a scale of institutional form ranging from representative houses in the UN, the increased representation of small states in international bodies and, in a form of subsidiarity, the devolution of public policy to the lowest practicable level. Indeed, Held's notion of 'double democratisation', both within states and across borders, represents one of the most 'practical' agendas for institutionalising cosmopolitan justice in the global polity. ${ }^{31}$

\section{Community and the global polity}

Although we might note the 'forward looking' qualities of cosmopolitanism, both in its ability to open debate on how we justify social arrangements and its attempt to

28 Molly Cochran, Normative Theory and International Relations: A Pragmatic Approach (Cambridge University Press, 1998), p. 28.

29 See Chris Brown, International Relations Theory: New Normative Approaches, p. 176.

30 See David Held, Democracy and the Global Order: From the Modern State to Cosmopolitan Governance (Cambridge: Polity, 1995), and Held and Anthony McGrew, Global Transformations: Politics, Economics and Culture (Cambridge: Polity, 1999).

31 For a defence of this position against some of the more commonly expressed criticisms from within IR, see Barry Buzan and David Held, 'Realism versus Cosmopolitanism', Review of International Studies, 24:3 (1998), p. 390. 
attach such a theory to extant social changes in the global polity, there are deep philosophical problems with such an account. Regardless of the complex institutional arrangements required to administer the kind of moral inclusion and redistributive justice which cosmopolitan theorists envisage, there are fundamental questions over the ontological primacy attributed to individuals and the resultant universalism it posits. From a communitarian perspective such universalism is rendered an inaccurate depiction of reality, or worse, one that could hasten a form of imperialism through ignorance to the social mores of different cultures.

A more critical reading of globalisation might highlight several different factors not given great consideration in the more optimistic (essentially economistic) liberal readings of cosmopolitanism. Whilst globalisation has been related to the transnational spread of communications and social relations through politico-economic contact, the idealistic view that this will result in some form of cultural homogeneity is severely questioned by the resurgence of religious, nationalist and ethnic politics in the post-Cold War world. Whilst we might forgo the alarmist proto-realist cultural determinism of authors like Samuel Huntington, it seems fair to recognise the remarkable proliferation of identity-based politics that challenge the 'Mc-World' of mainstream liberal discourse. ${ }^{32}$ Indeed many Southern and critical European schools of thought have challenged the liberal discourse of socioeconomic governance in the global polity as instances of Western (or more specifically, American) imperialism. In doing this they necessarily highlight the relevance of community and communitarian values in the global polity.

The communitarian tradition seeks to locate its ethical framework within the 'polis' as opposed to some external foundation. Against the universalism of cosmopolitanism, communitarians assert the particular 'truths' of different cultures and belief systems. Against the privileging of the individual over society they seek to understand the individual as the product of contingent social relations of a community. More fundamentally, communitarian thinkers locate moral value in the very social relations and the institutions they produce. Thus the modern values of liberty, equality and justice are not understood as abstract standards against which institutions, like the state or market, can be judged. Rather ethics are seen as constituted within those very institutions.

The 'social embeddedness' of market relations provides us with an example of how cultural differences emerge within the global polity. ${ }^{33}$ Production structures, organisational norms, and credit standards are all areas of human interaction. The social norms of such interaction are born of particular cultural understandings of reality prevalent in a given community. For example, in a communitarian analysis of the Asian financial crisis the IMF, rather than instituting a value-free universal standard of best economic practice, would be seen to be following a far more particularist line. If we view the IMF doctrines of transparency and accountability

32 Samuel Huntington, The Clash of Civilizations and the Remaking of World Order (London: Touchstone, 1998), and Benjamin Barber, Jihad vs. McWorld (New York: Ballantine Books, 1996).

33 The theme of social embeddedness in economic relations is well elaborated by the economic historians and sociologists. See for instance Karl Polanyi, The Great Transformation (Boston, MA: Beacon Press (1944), and Mark Granovetter, 'Economic Action and Social Embeddedness', in American Journal of Sociology, 91 (1985), pp. 481-510. 
as 'Western' values presaged upon the cultural dominance of the 'Anglo-Saxon' model of capitalism, then the recommendations for the break up of Asian financial and production frameworks becomes less a simple search for economic efficiency and also (or more) a case of breaking the cultural norms of South East Asian economic actors. On such a view we might further question whether Western economic actors receive (unfair) competitive advantages from these new arrangements ${ }^{34}$

In ethical philosophy, this idea of social embeddedness receives its most influential and complicated rendering in the quasi-mythological 'ethical state' of Hegelian thought. For Hegel the person is someone who is encumbered by social relations whilst able to realise freedom within them. The (ethical) state provides the context in which individuality and rules can be internalised so they are no longer regarded as constraints. As Chris Brown states: 'The state provides the element of unity necessary if the individual is to overcome the separateness inherent in civil society. ${ }^{35}$

By extrapolation, the communitarian dimension(s) of the global polity raise a number of questions for institutions with a transnational influence. A strong communitarian position sees the state as the sole arbiter of ethical value. This view sits well with the realist assertion that international cooperation will, at all times, be limited and transient depending upon the interests of (powerful) states. ${ }^{36}$ On weaker readings this view has underpinned many of the English School pronouncements upon the extent and limitations of international society. ${ }^{37}$ Robert Gilpin has taken the communitarian perspective to infer the importance of 'groups'. ${ }^{38}$ Thus his rational choice political economy of international relations sets out to understand, if not develop, the ethical value, of nations, classes and elites. ${ }^{39}$ More reflexive sociological positions highlight the complexity of community-based interaction in which the global polity has born witness to a proliferation of nations, ethno-nations and transworld national diasporas. In addition there has been a growth of non-territorial communities such as managerial class allegiances, women's movements, lesbian and gay solidarities, racial groups, religious groups/identities and a spread of global youth culture. ${ }^{40}$ In this complex web the emphasis is less upon the exclusivity of community in its demarcation of inside/outside binaries, but rather upon its capacity for penetration and hybridisation.

Despite the strengths of the communitarian ethical perspective for theorising the normative dimensions of the global polity, significant questions are evoked. For instance, Hegelian notions of the 'ethical state' might elicit acceptance for acts of

\footnotetext{
34 For a discussion along these lines see Richard Higgott, 'The Asian Economic Crisis: A Study in the Politics of Resentment', New Political Economy, 3:3 (1998) and Linda Weiss, 'State Power and the Asian Crisis', New Political Economy, 4:3 (1999), pp. 317-42.

35 Chris Brown, International Relations Theory: New Normative Approaches (New York: Columbia University Press, 1992), pp. 62-3.

36 See for instance Kenneth Waltz, Theory of International Politics (New York: McGraw-Hill, 1979).

37 Hedley Bull, The Anarchical Society: A Study of Order in World Politics (Basingstoke: Macmillan, 1977), remains the definitive statement on the English School position.

38 Robert Gilpin, 'The Richness of the Tradition of Political Realism', in R.O. Keohane (ed.), NeoRealism and its Critics (New York: Columbia University Press, 1986).

39 Gilpin, R., The Political Economy of International Relations (Princeton, NJ: Princeton University Press, 1987).

40 This sociological position is best reflected in the work of Jan Aart Scholte, Globalization: A Critical Introduction (Basingstoke: Macmillan, 2000).
} 
violence and infringements of 'justice' in the name of the 'greater project' of the state. Hegelian method could be criticised for licensing a form of cultural relativism that ignores the capacity of the state to do harm. Further, if we accept the worth of social mores then moral judgement is made equivalent to power, since much of the 'stuff' of ethical politics will be understood as functional between, rather than within, communities. On this basis, the development of justice in the global polity is beholden to those communities that have the power and the will to act. Thus much of the ethical agenda of the global polity can become tied to the (lack of) interest shown by the USA.

We would argue that these critiques are more than a question of taste. There is an overwhelming theoretical flaw in the predictive nature of many communitarian perspectives which delimit ethical deliberation to some reified conception of the 'art of the possible'. We would argue that there are, in fact, few straightforward conclusions to be drawn from the 'situatedness' of social experience, except that life is contingent. Despite its obvious qualities, communitarianism should caution against the danger of deriving an 'ought' from an 'is'. But, it is in the tension between cosmopolitan ideals and the communitarian 'art of the possible' that much normative international theorising has been conducted. The next section looks at a recent significant attempt to develop a 'thinner' cosmopolitanism as a middle way in this tension between cosmopolitan and communitarian ethics.

\section{Transcending the 'art of the possible'? Linklater and the 'art of synthesis'}

In the debate between cosmopolitans and communitarians we have what appears to be an intractable impasse inhibiting our ability to theorise the normative dimensions of the global polity. ${ }^{41}$ Against the trans-historical standard of 'justice as fairness', located in the universal rights of the individual, communitarians posit the social contingency of individual liberty. From this, two dangers arise. Firstly, the global polity might become conceived of as a 'zero-sum' ethical world in which we privilege either the individual (risking imperialism) or the community (risking despotism). Secondly, when framed in this way, the debate pre-favours a form of ethical compromise in which we strive for justice on individual and community lines whilst constantly qualifying that agenda with the realist(ic) 'art of the possible'. This wide acceptance of the fine balance between order and justice in international society has for too long led us to privilege the ethical limits of the global polity rather than search for its ethical possibilities. An attempt to transcend this conundrum can be found in the work of Andrew Linklater.

A cosmopolitan in orientation, Linklater employs Hegelian method to argue his case for reconstructing normative approaches to the social world. ${ }^{42}$ Echoing the

41 On the nature and implications of this impasse for International Relations, see Molly Cochran, Normative Theory and International Relations (Cambridge: Cambridge University Press, 1999).

42 See Andrew Linklater, The Transformation of Political Community: Ethical Foundations of the PostWestphalian Era (Oxford: Polity, 1998). See also his earlier work, Men and Citizens in the Theory of International Relations (London: Macmillan, 1990). 
intentions of Anthony Giddens to take seriously the limitations of social enquiry posited by the delegitimation of Marxism and the assault of postmodernism, Linklater extracts the core qualities of enlightenment thought and seeks to reapply them to a post-Westphalian system. ${ }^{43}$ Whilst strongly supportive of his attempt to reconstruct both the theory and practice of international relations we have three concerns. Firstly, our approach is sceptical of a notion of progress in human history that allows for the evolution of rationality in society through dialectical process. Secondly, we question the quasi-deterministic interpretation of praxeological development employed in Linklater's work. That humans can reflect on their surroundings and change them does not infer a capacity to know how to resolve their problems. And thirdly, we are critical of the employment of Habermasian 'discourse ethics' in Linklater's recent work. Habermas's notion of an 'ideal speech situation' is neither realistic nor does it resolve the dilemma that sooner or later a modernist framework must judge moral problems and risk undermining one or other concern against its own standard of truth. ${ }^{44}$ On our reading of Linklater, we see discourse ethics as concerned with 'right' not 'good', with procedure not content.

Accepting the constitutive properties of society for the individual, Linklater posits that social theory must contend with three central questions: the sociological question of community binaries of inclusion/exclusion, the normative question of achieving some cosmopolitan ideal of liberty and equality, and the praxeological question of how humans reflect upon and change their circumstances through time to achieve such ends. ${ }^{45}$ Thus Linklater's method rejects the more commonly understood rendering of the state as the final and ultimate source of 'actual reason' and looks to uncover the process by which reason has actualised itself in the past and will actualise itself in the future. He goes beyond the justice potentials of nonintervention and mutual recognition highlighted by the English School and seeks to illustrate how the development of citizenship rights in states has affected modern conceptions of justice in international affairs. By focusing on the potential of the conception of citizenship as a sign of a more inclusionary form of politics, Linklater asserts that the modern state has set in train a dialectical process that turns against itself. As he notes:

In modern times, it presses the anti-exclusionary dynamic in the evolution of modern citizenship further by considering its ramifications for the domain of world politics. The antiexclusionary dynamic is a trend of lowering the barriers which prevent excluded groups, such as subordinate classes, racial and national minorities, and women from enjoying the social and political rights monopolised by more powerful groups. To press this further is to recognise that the nation state is one of the few bastions of exclusion which has not had its rights and claims against the rest of the world seriously questioned. ${ }^{46}$

43 Anthony Giddens, A Contemporary Critique of Historical Materialism: The Nation-State and Violence (London: Polity, 1985).

44 We do not deal explicitly with Habermas' notion of an 'ideal speech situation' in this article. Briefly, the model rests on the assumption that reason is written into the discursive practices of society through language. Thus an objective standard of 'good' can be achieved through the rational development of clear communication. See The Theory Of Communicative Action, vol. 1: Reason And The Rationalization Of Society (London: Heinemann, 1984).

45 Andrew Linklater, 'The Question of the Next Stage in International Relations Theory: A Critical Theoretical Point of View', Millenium: Journal of International Studies, 21 (1992), pp. 77-98.

46 Ibid., p. 93. 
For Linklater, it is this dialectic, between reason already actualised and the ability of individuals and states to further actualise reason that will provoke the shift towards a post-Westphalian system. In this way the global polity might realise a greater level of moral inclusion. On the way, new forms of community that are national, subnational, regional or transnational will rise and fall with their own sociological inclusion/exclusion binaries. But, Linklater echoes some common cosmopolitan arguments by noting two factors in contemporary global politics that will support progress towards a moral community of humankind.

Firstly, there has been a growth in the scope and recognition of human rights in international law. The end of the Cold War has witnessed a profusion of both rhetorical and substantial humanitarian activities by states and non-state actors. Even if there is broad disagreement as to the shape and content of these rights, in practice they have served as a useful point of focus for people and groups seeking emancipation. And secondly, Linklater points to a global recognition of the requirement to meet the negative impacts of material inequality, environmental degradation, and the growing incidence of transnational harm: the evolving 'communities of fate' within global politics. He argues that the institutions of global governance, which monitor such communities, must address the democratic deficit in their operations via reform and greater engagement with civil society. ${ }^{47}$ As Molly Cochran surmises, these trends

... are a sign that we are moving beyond the men versus citizens moral dichotomy and that now our task is to envision new political forms which can further these developments. ${ }^{48}$

The final part of this transformation in moral and political community is to be found in Linklater's call for the development of Habermasian discourse ethics through a reconstruction of the idea of the state as a bounded moral community. He favours an open dialogue about the structure of society and politics as a means of achieving discourse ethics, but contends that this 'cannot be completed by a number of separate experiments in democratic participation within independent sovereign states', since sovereignty 'restricts the capacity of outsiders to participate in the discourse to consider issues which concern them.' ${ }^{49}$ When combined with questions of the communities of fate created by various incidents of transnational harm like global warming, 'casino' capitalism, and the exploitation of poor working standards, this could prove quite a powerful argument for a form of cosmopolitan social democracy via multi-level governance institutions.

While we find merit in Linklater's attempt to reconstruct social theory to reclaim the emancipatory potential of the enlightenment, it seems to overstate the capacity for political engagement in modern states. It is arguable that the widespread realisation of citizenship rights in Western countries has to some extent tranquillised rather than radicalised the forces of popular emancipation within society. More critically, those politicised activities which cosmopolitans can point to are most

47 See Linklater, A, 'The Evolving Spheres of International Justice', International Affairs, 75:3 (1999), pp. $473-82$.

48 Cochran, Normative Theory, p. 90.

49 Andrew Linklater, 'The Achievements of Critical Theory', in Smith Booth and Zalewski (eds.), International Theory: Positivism and Beyond (Cambridge: Cambridge University Press, 1996), p. 294, cit. Cochran, Normative Theory, p. 91. 
evident in the rich, northern, white, male, sections of the global polity. This poses a distinctive question to the content of any radical democracy associated with the ideal speech situation or discourse ethic: what is the requisite level of critical reflectivity required for 'enjoying' this situation? The principle of opening democratic conversation does not deal with the question of those people/groups who may refuse, or are unable, to join the dialogue.

Developing from this point, there is a sense in which discourse ethics might fudge the issue of political judgement. On one interpretation, it seems to underestimate the fact that at some point, even within overlapping and diffuse moral political communities, some form of judgement will have to be made. In Robert Jackson's words:

It is not a solution merely to argue for recognition and respect for the 'other' and his, her or their inclusion in the sphere of equality and entitlement. For inclusion only postpones the unresolved problem of determining which facet of the others' conduct ought to be recognised and respected and which not ... Exclusion and inclusion ultimately is not about class, sex, race, caste, nationality, and other sociological categories; it is about human conduct. ${ }^{50}$

It is this human conduct and, more particularly our ability to influence it that is the central issue in developing any normative agenda for the global polity.

\section{Richard Rorty and an ethic of pragmatic reform?}

We have suggested that the foundationalist positions reviewed thus far limit our capacity to theorise the normative dimension(s) of the global polity to the philosophical questions of 'what is?' - the nature of man, or the global polity - and then 'what should be?' Perhaps a more interesting/practical ethical question, derived from the philosophical pragmatism of Richard Rorty, might be to ask 'what could $b e$ ?'51 We would argue that the universal individual of the cosmopolitan and the particular social mores of the communitarian are not sacrosanct truths that can or should dictate the way we think about ethics under conditions of globalisation. This is not to deny the importance of ethical or theoretical discourse. Rather it is intended to humble theory. On this view we could continue to support the aim of political reconstruction through a post-national public sphere alluded to in Linklater's work. But, as the attempt to solve some of the extant social problems we encounter in a more effective way, rather than as the continuance of some application of timeless wisdom.

Digging deep into Rorty, we draw out three interrelated facets of this position: contingency, fallibility and experimentalism, that can be elaborated to both establish the pragmatic ethic and demonstrate the implicit necessity for those political and practical aspects of ethical theorising highlighted in this article.

50 Robert Jackson, 'Pluralism In International Political Theory', Review of International Studies (April 1992), p. 274. Emphasis added.

51 Richard Rorty, 'Human Rights, Rationality and Sentimentality', in Truth and Progress: Philosophical Papers (Cambridge: Cambridge University Press, 1998), p. 170. 
Contingency

Whereas the contingent nature of knowledge/ethics has created major tensions for the philosophers considered above, the pragmatic tradition of American philosophy has had no such insecurities. Rather than becoming transfixed by the nihilistic implications of cultural relativism, pragmatism seeks to identify and elaborate the useful aspects of contingent knowledge. As in MacIntyre's summary of Dewey's position:

We only acquired whatever knowledge we have now because we had certain purposes, and the point of that knowledge is inseparable from our future purposes. All reason is practical reason ... [T] o characterise something as good is to say that it will satisfy us in our purposes. $^{52}$

Richard Rorty takes up this theme to attack correspondence theories of truth and seeks to colour as romantic fallacy the very idea that the human mind is a separable entity that can mirror nature. It is fallacy that simply wastes our intellectual energy. ${ }^{53}$ The practical worth of philosophy is a recurrent concern of Rortian pragmatism and his scepticism is closely rivalled by the belief that in dispensing with truth we might develop a more useful contribution to political life. From this perspective, it can be argued that both cosmopolitans and communitarians, in their search for an ontological subject, undermine their own position by ignoring the contingency that they both, in some way, seek to engage. This is more than an abstract philosophical critique. It holds, we will argue, implications for the mindset we employ to theorise the normative dimension(s) of the global polity.

By stripping the foundation away from ethical debate, pragmatism tranquillises the impasse between the universal and the particular. Rorty echoes communitarian thought in believing that there is no Archimedean frame of reference outside the community. Practices and knowledge are constructed through interaction within a situated community. But Rorty does not infer a set of logical propositions based on the exclusivity of communal value systems. Instead he argues, ' . . the main lesson of both human history and anthropology is our extraordinary malleability.' ${ }^{54}$ Thus community values are in a state of constant development and revision. Our ability to promote a belief is in no way constrained by contingency since all individuals and all cultures, to some extent at least, seek to universalise their particular view of the world in exchanges with others and it is through such exchanges that universal positions become amended. ${ }^{55}$ For Rorty, linguistic tools have their purposes and so can be retired when that purpose is done, while other projects and other tools rise to supersede them. Rorty calls this a 'change of vocabularies'. In this regard, the adherence to a particular conceptual approach represents more a set of choices than a set of discoveries. ${ }^{56}$

Moreover, by emphasising malleability, pragmatism challenges the communitarian 'predictive' qualities emphasised in political realism. If communal value systems are

52 Cited in Brown, International Relations Theory, p. 207.

53 Richard Rorty, Philosophy and the Mirror of Nature (Oxford: Blackwell, 1980).

54 Rorty, 'Human Rights, Rationality and Sentimentality', p. 169.

55 Thanks to Owen Parker for his advice on this point.

56 For a discussion, see Simon Blackburn, 'Richard Rorty: A Portrait', Prospect (April 2003), pp. 56-60. 
in a condition of perpetual constitution through interaction then the art of the possible' could be regarded as a fairly myopic interpretation of the nature of contingency. Indeed when combined with themes of reflexive interpenetration and hybridisation we might argue that pragmatism can bring strength to cosmopolitan ideals by drawing a global map of moral communities that can be manipulated. Simply, if we want to universalise an ideal then that will surely involve a process of ethically 'lobbying' different communities to behave in certain ways. There is no concept of truth here, rather, ethics as an ideology.

Rorty has made some statements about how this kind of ethic could be related to international affairs. For example, he makes the argument that the theory and practical development of human rights in the international sphere does not rest upon the growing realisation of some ahistorical, transcultural truth about what constitutes human rights and how to implement them. Rather, he highlights the growth of a 'human rights culture' in the post-Holocaust world. Human rights need only cohere with our beliefs to gain massive support and practical application. Indeed, its success for Rorty owes 'nothing to increased moral knowledge, and everything to hearing sad and sentimental stories.' 57

The implications of such a mode of ethical reasoning for developing a normative agenda for the reform of the global economy are important and as yet barely articulated within the scholarly cum policy community concerned with such questions. We only need to look to the sentimental underpinning of concepts such as social welfare, just distribution, voice, representation, and indeed politicisation of the economic realm to realise just how much theoretical space could be found in this brand of pragmatism. Perhaps it is time for the community of scholars working in these policy areas to engage in Rortian experimentation. To the extent that it is fallible, this potential is, of course, problematic. We discuss the fallibility before we discuss the experimentalism.

\section{Fallibility}

Accepting the social contingency of knowledge, Rorty (unlike most communitarians) does not extrapolate a set of common principles that can be applied to all communities. Instead, he emphasises that contingency implies no frame of reference outside the community. The rhetorical style employed repeatedly uses words like 'we', 'western liberals', and perhaps most famously Rorty's quip that he himself is nothing but a 'post-modern bourgeois liberal'. 58

The ethical dimension of pragmatism is thus heavily imbued with a sense of irony, or 'fallibility'. When Rorty celebrates the 'liberal ironist' as someone who thinks 'cruelty is the worst thing we do', this (wet) optimism is qualified by the fact that liberal ironists must face '. . . up to the contingency of ... [their] . . own most

57 Richard Rorty, 'Human Rights, Rationality and Sentimentality', in Rorty, Truth and Progress: Philosophical Papers, vol. 3 (Cambridge: Cambridge University Press, 1998), p. 169.

58 See for instance Richard Rorty, 'Postmodernist Bourgois Liberalism', in Objectivity, Relativism and Truth: Philosophical Papers, vol. 1 (Cambridge: Cambridge University Press, 1991), pp. 197-202. 
central beliefs and desires'. ${ }^{59}$ This is because they believe that the contingency of knowledge means that there can be nothing but 'circular' justifications for political values. Although they might sympathise with the cosmopolitan urge to realise human dignity in a moral community of mankind, the liberal ironist cannot ignore the contingent construction of terms like 'dignity' and 'morality'. In essence, such words are always the discursive elements of social communication that represent the 'final vocabulary' of socially constituted individuals. ${ }^{60}$ Our final vocabulary might include words like 'justice' 'liberty', 'equality' or indeed 'community' or 'nation' but the meaning which others and ourselves attribute to them is relative. For Rorty, the self-doubt and circularity of knowledge leads to an ethic of redescription.

Accepting that beliefs are fallible, and any justification of them is in the final analysis an essentially circular act, pragmatism seeks to redescribe our final vocabularies. In the case of the individual this ethic might lead to attempts to realise personal freedoms of sexuality or creative interest. In the case of the community Rorty seeks to extend solidarity by expanding the 'we' group within which ethical deliberation takes place. In this he makes the simple observation that it is much easier to feel sympathy for people who are in some sense 'one of us'. Whilst we might follow Linklater and note an evolving 'thin community' of mankind that recognises collective fate and some form of global identity, it is but one amongst many instances of 'we-ness' along other community lines (race, nation, area, sex, class, and common history.) Reading back we could attribute to Marxism the redescription of class as a form of fraternal sympathy. Thus the real strength of international socialism may have been as a sentimental metaphor about togetherness in the face of hardship rather than any positivistic law of capital labour relations. As Rorty surmises, solidarity

... is to be achieved not by inquiry, but imagination, the imaginative ability to see strange people as fellow sufferers. Solidarity is not discovered by reflection, but created. . . . [It] is a matter of detailed description of what unfamiliar people are like and of redescription of what we ourselves are like. ${ }^{61}$

At root this kind of view is, of course, intensely relativistic and has led to one of the central criticisms of Rorty: his complacency towards institutions. If there is an inherent tension in the desire of individuals to redescribe their own vocabularies and the kind of social vocabularies that bind social collectivities then this form of fallibility must, in some way, destabilise institutions like the state, the market, education, the military, and psychological care in the community. This poses a question of central importance to any attempt to understand the political processes inherent in the search for a global polity. How does one choose between a radical resistance that ultimately obliterates institutions of governance and the maintenance and reform of those very institutions? For Rorty, this is not an irreconcilable problem.

At one level, he argues that institutions are not bound by foundational philosophy but by the 'social hope' that unites community. He cites the decline of religious faith

59 Richard Rorty, Contingency, Irony and Solidarity (Cambridge: Cambridge University Press, 1989), p. xv, cit. Molly Cochran, Normative Theory, p. 149.

60 Ibid., p. 79.

61 Ibid., xvi. 
in Europe that left modern institutions unaffected, judging that the new secular vocabularies were able to replace 'hope of heaven' with the 'hope of better social outcomes'. ${ }^{62}$ On this view, the Keynesian welfare state may have owed less to any socioeconomic truth, and more to its ability to bind European communities with the 'social hope' that they could leave behind the collective human suffering of World War II and fend off the new challenge of communism. At another level, Rorty concedes that the irony he celebrates could destabilise institutions. He therefore invokes a public/private split. Whilst the public rhetoric of his liberal utopia may remain historicist and nominalist - 'where public doubts are met not by Socratic requests for definitions and principles, but by Deweyan requests for concrete alternatives and programmes' - irony is a quality that he deems to be an 'inherently private matter'. ${ }^{63}$ On this view, solidarity must fulfil the (difficult) dual function of being both a critical, and a stabilising force. ${ }^{64}$ For example, the liberal values of individual freedom that catalysed civil rights groups in 1960s America presented a radical critique of US liberalism which have in turn reinforced liberalism's own legitimacy.

But Rorty's attempt to shore up Western institutions against the possibility of radical individualism nevertheless exhibits a complacency, or lack of interest not unfamiliar in most philosophical discourse, to issues of the international or global. The task for the twentieth century is to ask whether the ethic of redescription can be extended to the supraterritorial level. For example, on a minor reinterpretation we might propose that the construction of solidarity amongst communities interacting within the major international institutions such as the IMF, WBG, WTO, and the EU, could generate a pragmatic resolve to find more useful ways of talking about the world. Might not the introduction of Rortian 'irony' into the discourse of technocratic governance at the global level invoke a sense of doubt over the 'efficacy' of depoliticised economism of the type exhibited under the umbrella of the Washington consensus?

At an illustrative level, is it not possible to see the discourse of the postWashington Consensus, or what Harvard economist, Dani Rodrik, calls the 'augmented Washington consensus' in this light? In more general terms might it not prompt us to 'redescribe' the institutions of the global polity? In times of crisis, with no obvious way forward other than regime collapse, might the adoption of the Rortian irony provide mitigation of the bad-tempered discourse between the globaphiles and globaphobes that is currently polarising and paralysing meaningful policy change in the global economy? These are important questions for future research in international relations and the study of the role of the institutions of governance in the operation of the global political economy in particular.

\section{Experimentalism}

Pragmatism takes the contingency and fallibility of ethics to infer the demise of grand frameworks like cosmopolitanism and communitarianism. In their stead,

\footnotetext{
62 Richard Rorty, Contingency, Irony and Solidarity, pp. 85-6.

63 Ibid., p. 87.

64 Molly Cochran, Normative Theory, p. 150.
} 
Rorty advocates the development of moral imagination to redescribe our final vocabularies. Although intended to restrict pragmatism to reform within liberal democratic states, we suggest that with a minor reinterpretation, such an ethic could be productively applied at a number of levels in the global polity. It is through experimentalism that we feel pragmatism affords its most practical application. After reviewing Rorty's critique of Marxism we will set out the parameters for engaging a pragmatic praxis within the global polity. As Rorty noted in the wake of the fall of Communism in Russia and Eastern Europe:

I would hope that we have reached a time at which we can finally get rid of the conviction common to Plato and Marx that there must be large theoretical ways of finding out how to end injustice, as opposed to small experimental ways. ${ }^{65}$

He exhorts us to dispense with grand theoretical terms like 'anti-capitalist struggle' and instead substitute something banal and un-theoretical like 'the struggle against avoidable human misery' ${ }^{66}$ Critical politics could be supplemented by an ethical concern for notions like 'sympathy for human lives' and an agenda to create 'social hope' through the construction of solidarity, or we-ness, on issues relating to poverty, disease, famine, lack of representation, social alienation, or sociopolitical instability as a result of an utterly rigid financial architecture? In short, reformist or transformational politics could better concern itself with a sympathetic repetition of the words we can in the face of human suffering.

The experimentalism of this approach is twofold. Firstly, due to the contingency and fallibility of knowledge, a capacity to regard our agendas as potentially flawed in both motivation and outcome is vital. The experience of Communism in the USSR would illustrate the drawback of denying the possibility of failure. Secondly, perhaps more powerfully, the ability to regard such contingent social constructions as sympathy and solidarity as the bedrock of pragmatism brings a perpetual quality to reformism. It is a quality that is notably lacking on the agenda of international relations, of both the scholar and practitioner alike. Simply, the contingency of reform requires an ability to continually experiment with ways of understanding and creating sympathy and solidarity. The experimentalism of the pragmatic ethic means that human suffering is an ever-changing facet of reality, which requires innovative agendas for articulating and effecting responses. It is a perpetual reflex that requires greater elaboration in the global polity.

Thus we have in pragmatism an ethical agenda which points to many avenues. Accepting contingency, we might reinvigorate our belief in universalising a particular viewpoint on the basis that it might solve some of 'our' problems in a more effective way. The questions of who is 'we' and what is 'effective' are deemed as matters for ironic redescription. Thus at a certain point 'we' in Britain might convince ourselves of the 'effectiveness' of European level financial coordination via membership of the Euro and thus create a new 'we' for ethical deliberation. In doing so we will open both our institutions and understandings of solidarity to change through redescription.

65 Richard Rorty, 'The End of Leninism: Havel and Social Hope', in Truth and Progress: Philosophical Papers, vol. 2 (Cambridge: Cambridge University Press), p. 228.

66 Ibid., p. 229. 
Reading global politics in this way, a pragmatic ethic opens itself to more institutional questions than even Rorty envisages. This is no major challenge to pragmatism. Rorty, an American bourgeois liberal, is used to the effectiveness and exclusivity of US political structures. (Although he would probably not have expected the degree of exclusivity and imperialness of the American structures in the early years of the twenty-first century). For European social democrats, concerned with the possibilities of reconstructing welfare systems through European and global institutions for example, the pragmatic ethic can be adapted. Accepting the experimentalism of pragmatism, reformist politics are exhorted to have sympathy for human lives and find innovative agendas for both describing and rescribing those lives.

\section{Pragmatic redescription in the global polity: some early thoughts}

Can pragmatic redescription provide something more than just a principled wish list? At the very least it is a question worth further investigation. Here we can do no more than suggest alternative ways of thinking and acting. We start by noting that the development of a contingent fallible ethic of redescription should be a project for both scholars and practitioners alike. The scholarly study of globalisation and an emerging global polity must develop a critical problem-solving purpose that takes us beyond Robert Cox's once useful, but now inhibiting, distinction between international relations scholarship as either critical theory or problem-solving. ${ }^{67}$ By interpreting and redescribing discursive practices employed within the global polity (to date mostly the work of economists), philosophers and theorists of international relations should play a greater role in the development of the knowledge and power structures they contingently observe but have of late done little to affect. ${ }^{68}$ Throughout the twentieth century, political philosophers and international relations scholars ceded the policy ground to the economists in the domains of global economic governance. In the twenty-first century they must battle the economists for the role of pragmatic redescribers. Let us remember Keynes' famous quote about the power of ideas in full:

The ideas of economists and political philosophers, both when they are right and when they are wrong, are more powerful than is commonly understood. Indeed, the world is ruled by little else. ${ }^{69}$ (Emphasis added).

A pragmatic political praxis could be developed through 'acts of redescription' in the global polity. But it is not enough to endlessly theorise what the global polity is, we should also ask what could it be $?^{70}$ Is there, within the global polity, space for

${ }^{67}$ R. W. Cox, 'Social Forces, States and World Orders: Beyond International Relations Theory', in Robert

O. Keohane (ed.), Neorealism and Its Critics (New York: Columbia University Press, 1986), pp. 204-54.

68 This situation, and some of the reasons for it, is discussed in Higgott, 'Taming Economics'.

69 John Maynard Keynes, The General Theory of Employment, Interest and Money (London: 1936), p. 383.

70 One of the aims of producing the collection of essays on the 'global polity' (Higgott and Ougaard, Global Polity) was to provide an alternative hosting metaphor to the other popular metaphors of international scholarship like the 'anarchical society', 'international system' or a 'community of mankind'. 
developing new understandings of 'we-ness'? We would not, of course, wish to overstate this idea. We are a long way from the kind of bottom-up dialogic potentials that Habermas and Linklater advance. Instead the pragmatic ethic of contingent fallible reform must be focused upon achieving what can be achieved. In the context of the global polity, for example, the issue is to what extent the real potential of the international institutions for promoting global welfare can be achieved by acts of pragmatic redescription supporting incremental change in rhetorical agendas. Emphasis on the human dimension of markets (as social constructs) that has crept into recent policy initiatives associated with the post-Washington and augmented Washington consensus and debates over the delivery of global public goods, could be elaborated and reinforced by scholarly deliberation on their content and meaning. ${ }^{71}$

At another level, those academics that have 'discovered' the vanguard potential in global civil society for reconstructing democratic activity and elaborating social concerns should check the fallibility of their interest. ${ }^{72}$ Although civil society activists have undoubtedly made progress towards opening up a space in which to be heard within the recent discussion on globalisation, the content and democratic credentials of that voice are not viewed as unambiguously acceptable or beneficial in all quarters. 'Uncivil' society also abounds and some elements of the media are hostile on all occasions. Within the institutions of global economic governance, the relationship with civil society is clearly developing, ${ }^{73}$ but it is a process of experimentation in which uncertainty is a characteristic of, and for, both parties. The reformist potential of civil society is contingent, fallible, and experimental. If an agenda of reglobalisation, according to principles of social welfare, is to supplant the current agenda of anti-globalisation protest a discourse of pragmatism must gain ground. Support for pragmatic reformism can be found in strange quarters. See for example, the calls by George Soros for a new fund at the IMF for Special Drawing Rights for developing countries. ${ }^{74}$

'Feasible globalisations', not utopian alternatives, are required. Dani Rodrik, in one very interesting exercise in Rortian pragmatic redescription (although Rodrik, as an impeccably trained economist, would probably not recognise it as such) argues for a reform of the global market-governance nexus. The political trilemma of the global economy, he says, is the incompatibility of the continued existence of the nation state (to ensure self-determination), the development of democratic politics beyond the state (to ensure that public policy is accountable) and the continuing

71 See Dani Rodrik, 'After Neoliberalism, What?' After Neoliberalism: Economic Policies that Work for the Poor, Conference sponsored by the New Rules of Global Finance Coalition, Washington DC, 23-24 May 2002, pp. 11-20, and Inge Kaul, Pedor Conceicao, Katell Le Goulven and Ronald Mendoza, Providing Global Public Goods: Managing Globalisation (New York: Oxford University Press for the UNDP, 2003).

72 See Robert Cox, 'The Global Political Economy and Social Choice', in Robert W. Cox with Timothy J. Sinclair (eds.), Approaches to World Order (Cambridge: Cambridge University Press, 1996).

73 See a report prepared by Jan Art Scholte for the Ford Foundation, Democratising the Global Economy: The Role of Civil Society (Warwick University: Centre for the Study of Globalisation and Regionalisation, 2003), and Jan Aart Scholte and Albrecht Schnabel (eds.), Civil Society and Global Finance (London: Routledge, 2001).

74 See George Soros, On Globalisation (New York: Rowman and Littlefield, 2002). For a discussion of this and other initiatives, see the Richard Higgott and Paolo Robbotti, Reshaping Globalisation: Multilateral Dialogues and New Policy Initiatives (Budapest: Central European University, 2002). 
economic integration of the global economy to enhance living standards. ${ }^{75}$ At best we can secure two of these three goals, never all of them, and global markets (economic integration) without global governance are unsustainable.

The current neoliberal agenda (as reflected, for example, in US strategy in the Doha round of multilateral trade negotiations with its emphasis on the continuing elimination of barriers to trade and capital movements) reflects an aggressive drive for enhanced (deep) global economic integration. But such integration sits at odds with the residual strength of nation states and the clamour for democratic politics. It thus remains neither feasible nor desirable, says Rodrik, to continue towards global economic integration greater than is compatible with the desires of nation states and the expansion of democratic accountability. Thus we need to think, more pragmatically, of what can be achieved. For Rodrik, the alternative is:

... a renewed Bretton Woods Compromise: preserving some limits on integration, as built into original Bretton Woods arrangements, along with some more global rules to handle the integration that can be achieved. Those who would make different choices - towards tighter economic integration - must face up to the corollary: either tighter world government or less democracy. ${ }^{76}$

In an era when who wins and who loses are becoming increasingly important yardsticks for judging the fairness of competing models of economic organisation we might need to '... scale down our ambitions with respect to global economic integration ... [and] ... do a better job of writing the rules for a thinner version of globalization'. ${ }^{77}$ Why is Rodrik's argument an important exercise in Rortian redescription? Four reasons:

1. The argument is not self-evident within the community of neoclassical economists from which Rodrik emanates. Rather, he assumes that markets are embedded in a non-market social institutional context. To readers of literature influenced by Karl Polanyi or John Ruggie over the last twenty years this may not seem particularly dramatic. In the context of the post-1990s neoliberal economic orthodoxy, it is transformative.

2. Rodrik accepts the reality of a wide divergence of both functions and form in the nature of capitalist institutional economic organisation. Again, there is a large body of continental European (social-democratic) and Asian (developmental statist) literature on the institutional arrangements of capitalist economic organisation. It is the extent to which Rodrik's position runs counter to much Anglo-American economic orthodoxy on the legitimacy of alternative forms of institutional economic organisation that makes for an important redescription.

3. His argument eschews the essentialist teleological logic of the neoliberal view of globalisation, one in which full global economic integration is the ultimate goal.

4. In an era when traditional restrictions on trade and investment (such as tariffs) are much less salient than in the second half of the twentieth century, juris-

75 Dani Rodrik, 'Feasible Globalisations',

$<$ http://ksghome.harvard.edu/ .drodrik.academic.ksg/papers.html>

76 Ibid., p. 1.

77 Ibid., p. 2. 
dictional and regulatory instruments emanating from state actors are the major constraints on deep integration. Attempts to remove these inhibitors (part of the WTO agenda) can only be justifiable, argues Rodrik, if one ignores the important sociopolitical and cultural functions that such institutions perform. The dismissal of the importance of these functions has been central to neoliberal economic thinking in the heyday of globalisation that dominated the closing quarter of the twentieth century. Hence Rodrik's assertion of their virtue, and the need to tread carefully in their dismantling, represents a departure from orthodox thinking about the management of globalisation.

In turning away from these key elements of neoliberal economic orthodoxy, yet without resisting the essential importance of market activity and structures, Rodrik is engaged in a major exercise in what we have chosen to call Rortian pragmatic redescription. Such an approach to trying to develop an ethic of globalisation is not found amongst either the globalisation boosters or much of the anti-globalisation movement that generate more heat than light in current discussions about how we might either manage or change the contemporary global economic order.

Finally, an ethical agenda must provide social hope. The construction of 'we-ness' cannot look backwards and find some transhistorical, transcultural 'proof' of human community or equality. Instead a pragmatic ethic must look forward to finding a 'we' that can talk more usefully about issues of transnational interdependence. If, for example, we are to universalise a belief in a reconstruction of systems of welfare that are analogous to an earlier Keynesian ethic, then an innovative redescription of the global polity - as a collection of human beings that share a capacity to suffer and an ability to mitigate that suffering - is required.

\section{Conclusion}

In this article we have offered but one way of trying to carve out some space for ethical thinking beyond the borders of the modern state in an era of globalisation. Like Rorty, who we think does himself a disservice in his self-description as a 'postmodern bourgeois liberal' our views are very much reformist. Two quotes, extracted from Chris Brown's delightfully cheeky last chapter to his Sovereignty, Rights and Justice volume, capture a key essence of this article. Citing the banner at the London 2001 May Day Rally - 'Replace capitalism with something nicer' - Brown hopes it is meant to be humorous. ${ }^{78}$ So do we. It reflects the total lack of a positive agenda for change, rather than a negative agenda of mere resistance, that infuses much of the anti-globalisation movement. Again citing Rorty, '... . [if] you still long for total revolution, for the Radical Other on a world historical scale, the events of 1989 show that you are out of luck'. ${ }^{79}$

A strategy of redescription, as part of a reformist strategy, assumes that the reform of capitalism has to be possible. We suspect it will not please observers on

\footnotetext{
78 Brown, International Relations Theory, p. 237.

79 Ibid., p. 239.
} 
either end of the globalisation-anti-globalisation continuum. But, we would argue current problems in the global economy (indeed the global order in general) notwithstanding - that there is nothing to suggest that the market economy is likely to disappear in a hurry. Other world ideologies are not lining up to replace it. Reform has to be the order of the day. The ethical redescription of globalisation needs to be a starting point for that process. Philosophers, theorists and practitioners of IR must join economists as key players in this process in the first decade of the twenty-first century in a way that they were not in the closing decade of the twentieth. 
